\title{
PENERAPAN SISTEM INFORMASI KAMPUNG BANDAR AGUNG BERBASIS WEB UNTUK ADMINISTRASI WARGA
}

\author{
Alam Fathurochman ${ }^{1}$, Muhammad Iqbal ${ }^{2}$, Hersa Dwi Yanuarso ${ }^{3}$, Mugi Praseptiawan ${ }^{4}$ \\ ${ }_{1,2,3,4}$ Institut Teknologi Sumatera, Bandar Lampung, Indonesia \\ email: alam.fathurochman@itera.ac.id
}

\begin{abstract}
The village government as a public service institution in the community has a bad stereotype due to the many shortcomings of the services provided. Problems that usually arise include: slow service, filing that takes a long time, long administrative lines, and administrative errors so that the service people get is not optimal. These problems can lead to harmful practices such as bribery or brokers that add to the bad image of public services. The breakthrough to overcome problems and improve the quality of public services is the application of information technology. The "Kampung Bandar Agung" government is in charge of managing the administrative implementation of the residents. The current condition of administrative management of services to the community is still conventional or manual. Based on these problems, it is necessary to have an information system to manage the administrative services of the Kampung Bandar Agung community. A website-based information system can be a solution to keep data and information more secure and quickly accessed. The design of this website-based village information system uses the OpenSID application, which has complete features in the form of a village service administration module and a website that is used to provide information related to village government activities. The feedback results through interviews and discussions with partners, namely the Bandar Agung Village Government, community service activities by creating a website-based village information system are very helpful for the innovation of the "Kampung Bandar Agung" community service.
\end{abstract}

Keywords: Village Information System, Website, Village Government

\begin{abstract}
Abstrak: Pemerintah desa sebagai lembaga pelayanan publik di masyarakat memiliki streotip kurang baik akibat banyak kekurangan dari pelayanan yang diberikan. Masalah yang biasanya timbul antara lain: lambatnya pelayanan, pemberkasan yang membutuhkan waktu cukup lama, alur administrasi yang panjang serta kesalahan-kesalahan administrasi sehingga pelayanan yang didapatkan masyarakat tidak optimal. Permasalahan tersebut dapat memunculkan praktik-praktik tidak baik seperti suap atau calo yang menambah potret buruk terhadap pelayanan publik. Terobosan untuk mengatasi permasalahan dan meningkatkan kualitas pelayanan publik adalah penerapan teknologi informasi. Pemerintah Kampung Bandar Agung bertugas mengelola pelaksanaan administratif warga. Kondisi saat ini pengelolaan administratif layanan kepada masyarakat masih konvensional atau manual. Berdasarkan permasalahan tersebut, diperlukan adanya sistem informasi untuk mengelola administratif pelayanan masyarakat Kampung Bandar Agung. Sistem informasi berbasis website dapat menjadi solusi untuk menjaga data dan informasi lebih aman dan secara cepat diakses. Perancangan sistem informasi desa berbasis website ini menggunakan aplikasi OpenSID yang secara lengkap memiliki fitur-fitur berupa modul administrasi pelayanan desa serta website yang digunakan untuk memberikan informasi terkait aktivitas pemerintah desa. Hasil umpan balik melalui wawancara dan diskusi dengan pihak mitra, yakni Pemerintah Kampung Bandar Agung, kegiatan pengabdian kepada masyarakat dengan pembuatan sistem informasi desa berbasis website ini sangat membantu terhadap inovasi pelayanan warga Kampung Bandar Agung.
\end{abstract}

Kata Kunci: Sistem informasi desa, Website, Pemerintah desa

\section{Pendahuluan}

Perkembangan teknologi menjadi pendorong kemajuan manusia dalam beraktifitas sehingga dapat mempermudah aktifitas atau pekerjaan menjadi lebih efektif dan efisien (Mustamiin, Permana Putra, \& Darsih, 2020). Inovasi yang muncul pada beberapa dekade 
terakhir merupakan dampak dari perkembangan teknologi informasi (Nursetiawan, 2020). Kondisi perkembangan teknologi juga telah mempengaruhi keseluruhan aspek kehidupan masyarakat sehingga secara tidak langsung diharapkan mampu memahami dan menguasai teknologi. Tidak terkecuali aspek pemerintahan di pedesaan, pemanfaatan teknologi informasi dibutuhkan untuk memenuhi ketersediaan informasi dan pembangunan desa (Prihatiningtyas dkk., 2020).

Pemerintah desa sebagai lembaga pelayanan publik di masyarakat memiliki streotip kurang baik akibat banyak kekurangan dari pelayanan yang diberikan. Beberapa masalah yang biasanya timbul, antara lain: lambatnya pelayanan, pemberkasan yang membutuhkan waktu cukup lama, alur administrasi yang panjang serta kesalahankesalahan administrasi sehingga pelayanan yang didapatkan masyarakat tidak optimal (Mahayoni \& Wirantari, 2021). Permasalahan tersebut dapat memunculkan praktikpraktik tidak baik seperti suap atau calo yang menambah potret buruk terhadap pelayanan publik. Salah satu terobosan untuk mengatasi permasalahan dan meningkatkan kualitas pelayanan publik adalah penerapan teknologi informasi.

Penerapan teknologi informasi yang dapat digunakan adalah sistem informasi desa berbasis website. Sistem informasi desa merupakan elemen yang masuk dalam impelementasi Undang-Undang Desa terutama pasal 86 tentang Sistem Informasi Pembangunan Desa dan Pembangunan Kawasan Perdesaan yang mengatakan bahwa desa berhak mendapatkan akses informasi melalui sistem informasi yang dikembangkan oleh Pemerintah Daerah Kabupaten atau Kota (Polii, Rindengan, \& Karouw, 2017). Sistem Informasi Desa merupakan sebuah aplikasi yang diterapkan untuk mendukung pengelolaan data sumber daya dan pelayanan administrasi warga di tingkat desa. Aplikasi ini bersifat open source sehingga siapa saja dapat menggunakan dan memperbaiki aplikasi untuk dikembangkan (Candra \& Attijani, 2021). Sistem Informasi Desa banyak memberi manfaat secara langsung bagi desa, diantaranya: meningkatkan efektifitas dan efisien, menjadi lebih transparan, meningkatkan layanan publik, akuntabilitas bertambah, partisipasi warga dapat lebih aktif dalam pembangunan desa, serta kualitas akses informasi desa oleh warga lebih baik (Fahri, 2020).

Di Indonesia beberapa daerah sudah melakukan penerapan sistem informasi desa pada pemerintahan desanya. Beberapa diantaranya adalah Pemerintahan Desa Wonokarto di Provinsi Lampung dan Desa Bona di Provinsi Bali. Kedua desa tersebut membuka informasi dan pelayanan administratif warga melalui sistem informasi berbasis website. Hasil yang didapatkan yaitu penyelenggaraan pemerintahan desa yang efektif, efisien, transparan dan akuntabel (Mahayoni \& Wirantari, 2021). Kemudian penerapan sistem informasi desa berbasis website juga memberikan dampak kemudahan masyarakat desa untuk mendapatkan program kerja dan informasi desa dimanapun dan kapanpun warga berada (Polii dkk., 2017).

Desa Bandar Agung atau dalam hal ini Kampung Bandar Agung merupakan wilayah yang berada di Lampung Tengah dengan luas 1.771 hektare dengan jumlah penduduk \pm 5.548 jiwa. Pemerintah Kampung Bandar Agung bertugas mengelola pelaksanaan administratif warga Bandar Agung (Nurjannah, Sugiyanta, \& Zulkarnain, 
2013). Kondisi saat ini pengelolaan administratif layanan kepada masyarakat masih konvensional atau manual sehingga ditemukan permasalahan seperti lamanya waktu pencarian data, pencatatan data atau informasi serta tidak jarang juga kehilangan data yang berkaitan dengan administratif warga.

Berdasarkan permasalahan tersebut, diperlukan adanya sistem informasi untuk mengelola administratif pelayanan masyarakat Kampung Bandar Agung. Sistem informasi berbasis website dapat menjadi solusi untuk menjaga data dan informasi lebih aman dan secara cepat diakses. Selain itu kondisi pandemik yang memerlukan sistem yang dapat melayani secara daring, dokumen berbasis digital dan juga menghindari interaksi secara langsung.

\section{Metode}

Pengabdian kepada masyarakat dilaksanakan melalui proses Community Based Research $(C B R)$. CBR merupakan metode pendekatan penelitian kolaboratif yang melibatkan semua pemangku kepentingan selama proses penelitian (Putri, 2021). CBR dalam definisi lain disebutkan sebagai sebuah kerjasama dalam riset serta saling menguntungkan antara peneliti kampus dengan komunitas yang bertujuan untuk sebuah gerakan sosial dan perubahan sosial dengan tujuan akhir untuk mencapai keadilan sosial (Hanafi dkk., 2015). Tahapan dalam CBR terbagi menjadi empat, yaitu peletakan dasar (laying foundation), perencanaan (planning), pengumpulan dan analisis data (information gathering and analysis) dan aksi terhadap temuan (acting on finding).

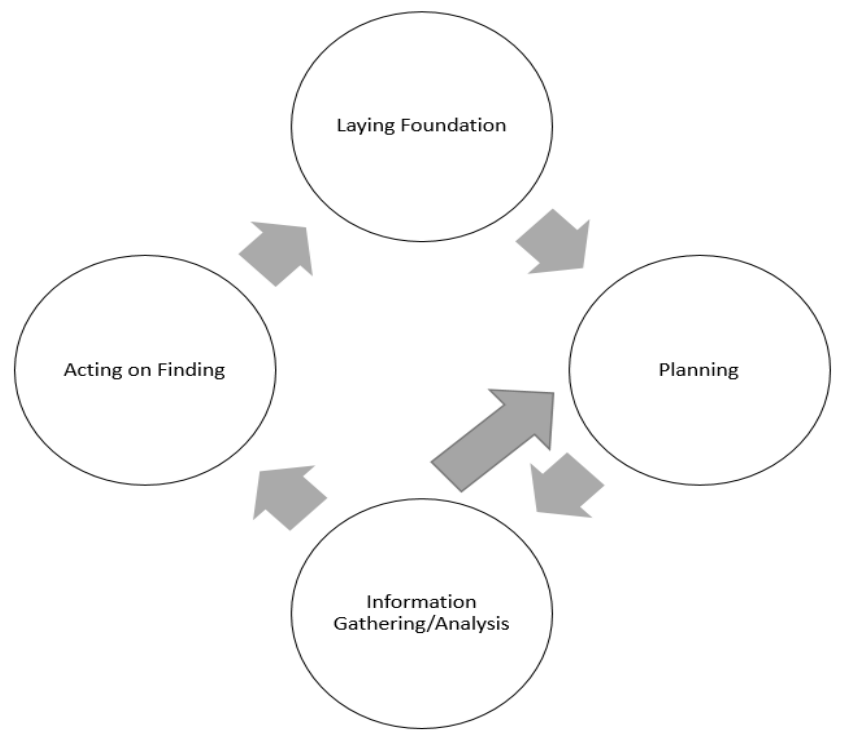

Bagan 1. Tahapan Community Based Research

Langkah pelaksanaannya dalam konteks pengabdian kepada masyarakat ini adalah sebagai berikut:

\section{Laying Foundation}

Langkah pertama ini adalah diskusi dan komunikasi dengan melibatkan mitra pengabdian untuk mengidentifikasi sumber daya, kebutuhan, kepentingan, masalah umum dan tujuan. 


\section{Planning}

Langkah kedua adalah tahap perencanaan pelaksanaan kegiatan pengabdian terhadap informasi yang telah didapatkan dari hasil diskusi dan komunikasi tim dan pihak mitra pengabdian.

\section{Information Gathering/Analysis}

Pada langkah berikutnya adalah mengumpulkan, menganalisis dan mengintrepretasi data yang dihasilkan dari pelaksanaan kegiatan pengabdian tim dan mitra.

\section{Acting on Finding}

Langkah yang terakhir adalah memobilisasi pengetahuan dan masyarakat terhadap hasil penelitian. Pada langkah ini dapat diimplementasikan melalui, sosialisasi, pelatihan dan penulisan artikel.

\section{Hasil dan Pembahasan}

Kampung Bandar Agung Kecamatan Terusan Nunyai Kabupaten Lampung Tengah saat ini berdasar diskusi dan komunikasi yang dilakukan pada awal pelaksanaan kegiatan sedang bersemangat untuk melakukan inovasi-inovasi dalam peningkatan pelayanan masyarakat. Salah satu inovasi pelayanan kepada masyarakat yaitu mitra membutuhkan pembuatan website sistem informasi desa. Website ini menurut pihak mitra dibutuhkan untuk melakukan pelayanan administrasi dan juga menampilkan informasi atau kegiatan pemerintah kampung.

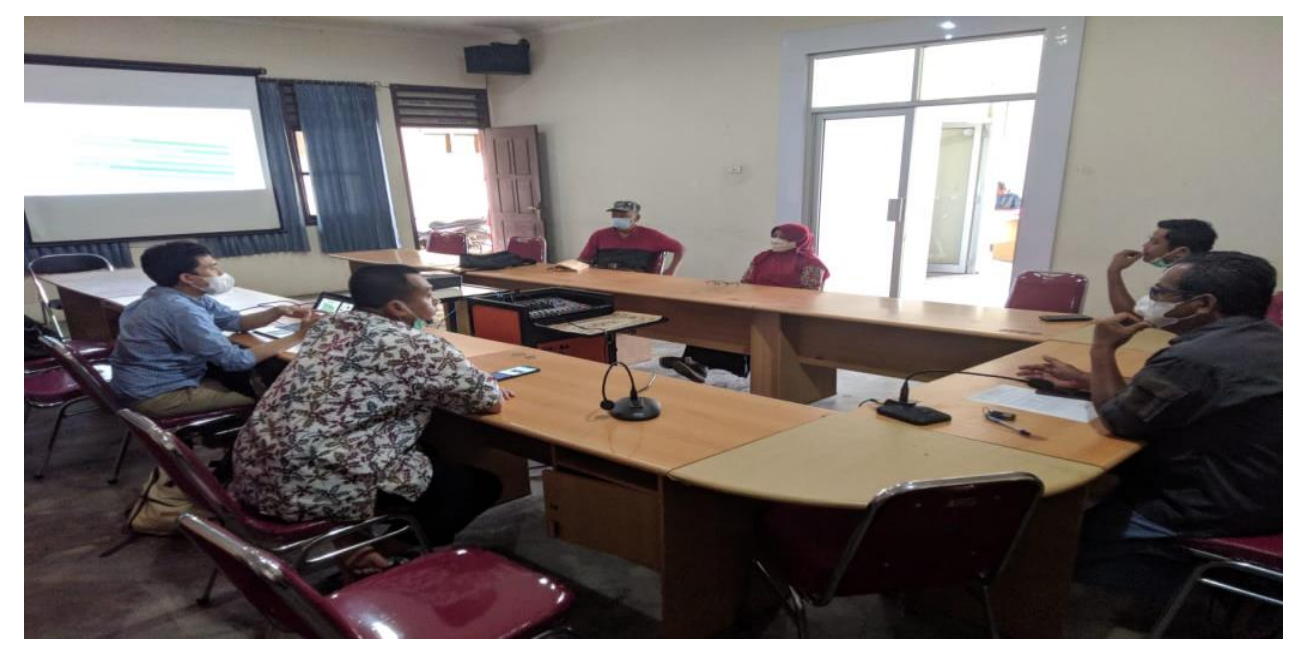

Gambar 1. Tahapan Diskusi Dan Komunikasi Tim Dan Mitra Pengabdian Kepada Masyarakat

Selanjutnya dilakukan pembuatan website sistem informasi desa menggunakan aplikasi open source yaitu OpenSID. Arsitektur dari sistem informasi desa berbasis website ini memiliki tiga layer yaitu layer pertama untuk pengaturan tampilan web menggunakan bahasa pemrograman JQuery, HTML, dan CSS; layer kedua sebagai inti dibuat dengan bahasa PHP dan Apache sebagai server kemudian layer ketiga sebagai bagian database menggunakan MySQL.

Hasil pembuatan website sistem informasi Kampung Bandar Agung secara lebih lanjut akan dijelaskan sebagai berikut: 
Jurnal Pengabdian Masyarakat As-Salam (JPMA)

Vol. 1 No. 2 Juli - Desember 2021: 57 - 64

Alam Fathurochman, Muhammad Iqbal, Hersa Dwi Yanuarso, Mugi Praseptiawan

a. Halaman Utama (Homepage)

Halaman utama merupakan tampilan pertama ketika penggunan memasukan nama website Kampung Bandar Agung. Pada halaman utama terdapat menu Beranda, Profil Desa, Pemerintah Desa, Data Desa, Kontak, Regulasi, Peta dan Login. Gambar 2 merupakan tampilan homepage website sistem informasi desa Kampung Bandar Agung.

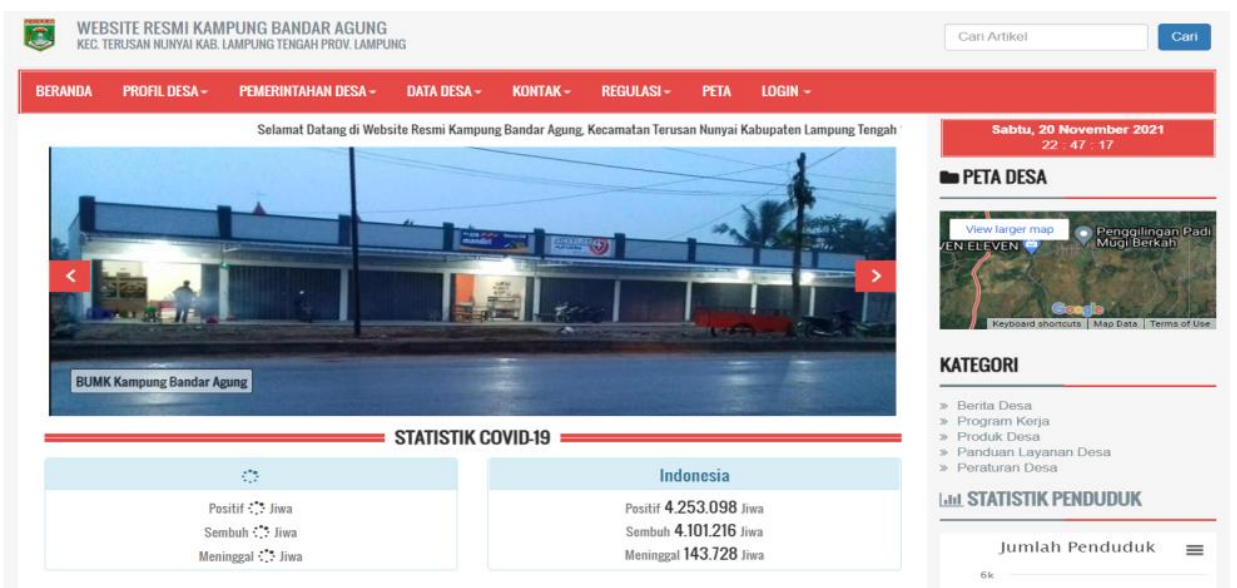

Gambar 2. Halaman Utama Website Sistem Informasi Desa Kampung Bandar Agung

b. Dashboard Admin

Dashboard Admin atau operator dapat diakses pada menu LOGIN yang ada di Homepage dengan memilih sub menu Administrator. Admin atau operator desa melakukan login ke sistem (tampilan menu login admin lihat Gambar 3 dan Gambar 4) untuk mengelola data, update informasi dan pelayanan administrasi warga.

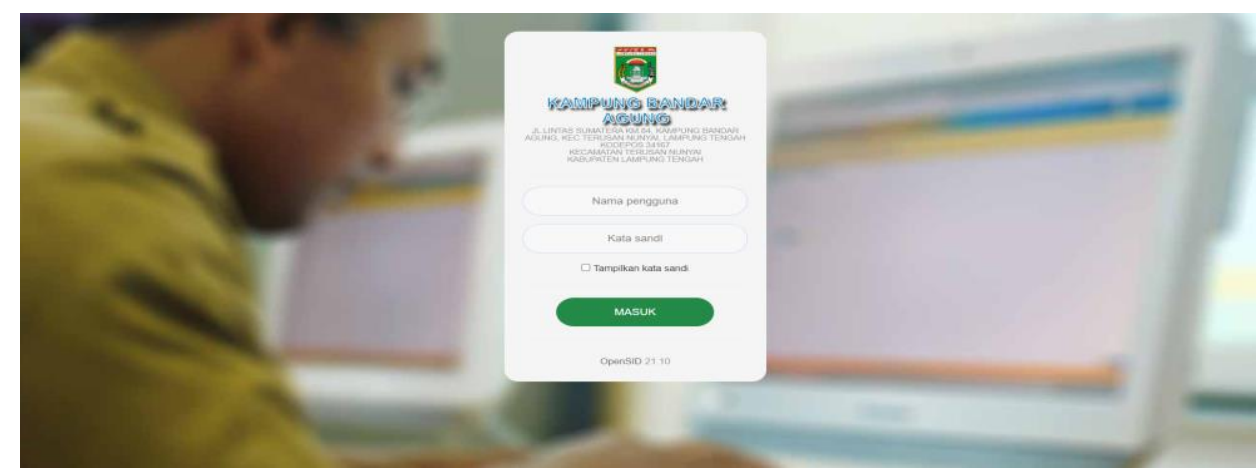

Gambar 3. Tampilan Login Admin Ke Dashboard

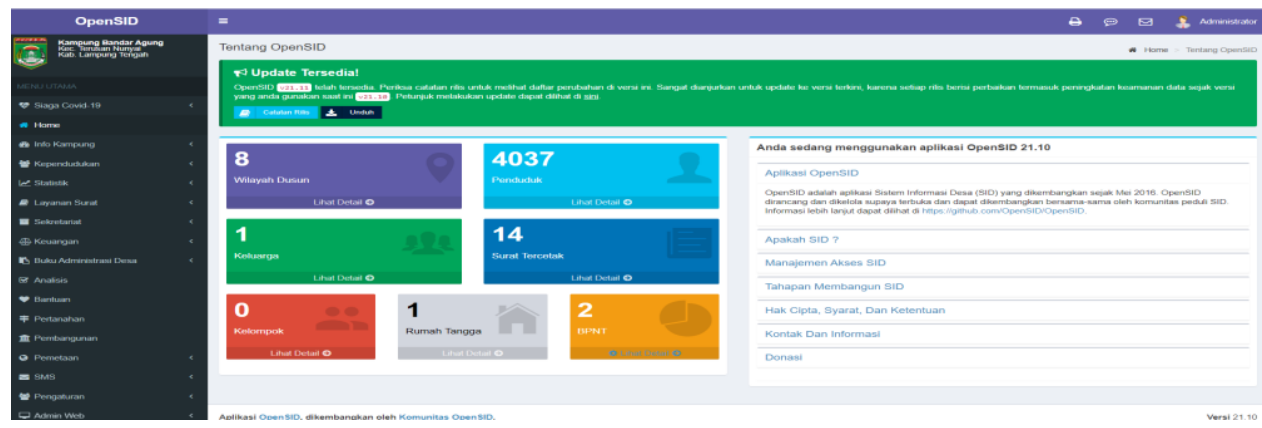

Gambar 4. Tampilan Dashboard Admin 


\section{c. Dashboard Layanan Mandiri}

Warga Kampung Bandar Agung melalui website dapat melakukan pelayanan administrasi secara mandiri, seperti kebutuhan pembuatan surat usaha, surat keterangan penduduk, surat keterangan pengantar dan lain-lain. Warga bisa melakukan layanan mandiri melalui pilihan menu Login dan pilih sub menu Layanan Mandiri. Berikutnya warga akan diarahkan ke halaman login dengan memasukkan NIK dan pin yang telah diatur ulang oleh warga tersebut (lihat Gambar 5). Jika berhasil masuk, warga akan masuk ke dashboard akun masing-masing dengan empat menu utama yaitu Profil, Surat, Pesan dan Bantuan. Menu Surat digunakan untuk melakukan pelayanan mandiri pembuatan surat administrasi.

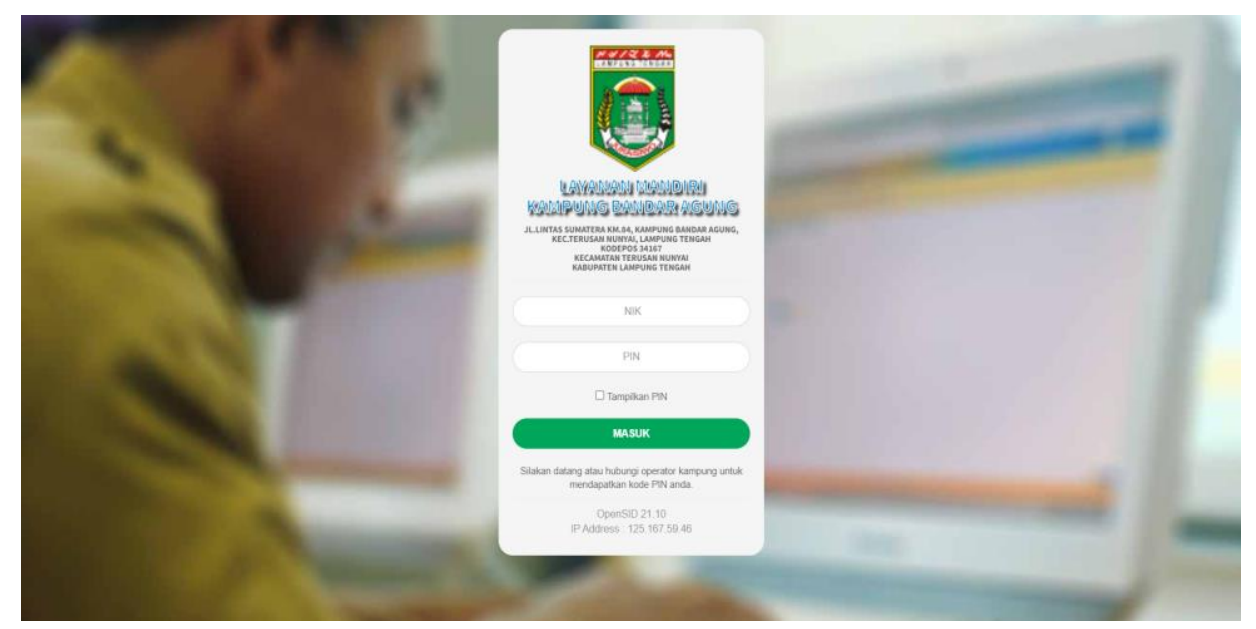

Gambar 5. Tampilan Login Pada Menu Layanan Mandiri

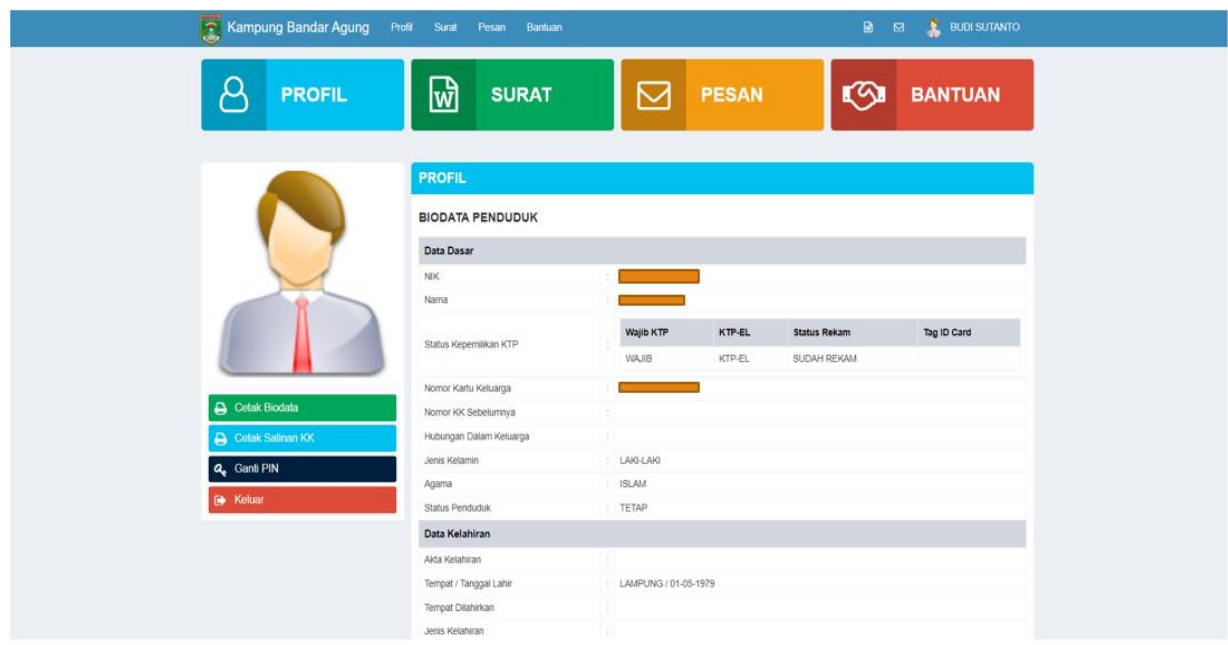

Gambar 6. Tampilan Dashboard Akun Masing-Masing Warga Pada Layanan Mandiri

Sebagai tahapan berikutnya dalam pengabdian ini adalah melakukan sosialisasi dan workshop kepada warga serta perangkat pemerintah Kampung Bandar Agung. Sosialisasi dan workshop ini untuk mendiseminasikan hasil kerja serta menambah wawasan tentang teknologi informasi kepada warga dan perangkat daerah. Tahapan ini juga sebagai langkah untuk mendapatkan umpan balik dengan tujuan berjalannya proses perbaikan yang berkelanjutan. 
Jurnal Pengabdian Masyarakat As-Salam (JPMA)

Vol. 1 No. 2 Juli - Desember 2021: 57 - 64

Alam Fathurochman, Muhammad Iqbal, Hersa Dwi Yanuarso, Mugi Praseptiawan

\section{Kesimpulan}

Pengabdian kepada masyarakat bekerja sama dengan Pemerintah Kampung Bandar Agung menerapkan Community Based Research (CBR) yang secara umum dalam melakukan proses penelitiannya melibatkan komunitas atau mitra dalam setiap tahapannya. Permasalahan yang muncul adalah mitra membutuhkan inovasi untuk peningkatan pelayanan administrasi warga desa dan kebutuhan informasi agenda-agenda pemerintah desa dalam pembangunan. Sistem informasi desa berbasis website menjadi solusi dalam tujuannya untuk meningkatkan optimalisasi pelayanan administrasi warga dan penyebaran informasi kegiatan pembangunan pemerintah Kampung Bandar Agung. Perancangan sistem informasi desa berbasis website ini menggunakan aplikasi OpenSID yang secara lengkap memiliki fitur-fitur berupa modul administrasi pelayanan desa serta website yang digunakan untuk memberikan informasi terkait aktivitas pemerintah desa.

Hasil umpan balik melalui wawancara dan diskusi dengan pihak mitra, yakni Pemerintah Kampung Bandar Agung, kegiatan pengabdian kepada masyarakat dengan pembuatan sistem informasi desa berbasis website ini sangat membantu terhadap inovasi pelayanan warga Kampung Bandar Agung. Harapan pihak mitra kegiatan ini dapat dilakukan bimbingan dan juga penambahan fitur lainnya untuk pelayanan kepada warga untuk lebih baik ke berbagai aspek kehidupan.

\section{Ucapan Terima Kasih}

Penulis mengucapkan terima kasih kepada Lembaga Penelitian dan Pengabdian Kepada Masyarakat yang telah memberi dukungan pendanaan terhadap pengabdian ini melalui program Hibah Penelitian dan Pengabdian ITERA Tahun 2021. Dan Pemerintah Kampung Bandar Agung yang telah bekerja sama dalam kegiatan pengabdian kepada masyarakat.

\section{Daftar Pustaka}

Candra, D. S., \& Attijani, A. (2021). SISTEM INFORMASI DESA Tutorial Praktek Instalasi dan Penggunaan Aplikasi Web. Probolinggo: Repository Universitas Panca Marga. http://repository.upm.ac.id/id/eprint/1810

Fahri, M. U. (2020). Sistem Informasi Desa. Ketapang: Akademi Manajemen Komputer dan Informatika (AMKI) Ketapang.

Hanafi, M., Naily, N., Salahuddin, N., Riza, A. K., Zuhriyah, L. F., Muhtarom, Dahkelan. (2015). COMMUNITY BASED RESEARCH Panduan Merancang dan Melaksanakan Penelitian Bersama Komunitas.

Retrieved November 19, 2021, from http://digilib.uinsby.ac.id/41749/1/Abdul Muhid_Community Based Research.pdf

Mahayoni, G. A. D. I., \& Wirantari, I. D. A. P. (2021). Pengembangan Website Desa Dalam Meningkatkan Kualitas Pelayanan Publik di Desa Bona, Gianyar. Journal of Contemporary Public Administration, 1(1), 13-19.

https://doi.org/10.22225/jcpa.1.1.3311.13-19

Mustamiin, M., Permana Putra, W., \& Darsih. (2020). Pelayanan Elektronik Masyarakat Desa Sebagai Penerapan Smart Village Pada Desa Sleman Lor. Ikraith-Abdimas, 
$3(2), 1-7$.

Retrieved from file:///D:/Downloads/483-Article Text-674-1-10-20191112.pdf

Nurjannah, U., Sugiyanta, I. G., \& Zulkarnain. (2014). Tinjauan Geografis Lokasi Pasar Bandar Agung Desa Bandar Agu Ng Kecamatan Terusan Nunyai Kabupaten Lampung Tengah Tahun 2013. Jurnal Penelitian Geografi, 2(7), 14-27.

http://jurnal.fkip.unila.ac.id/index.php/JPG/article/view/6683

Nursetiawan, I. (2020). Peningkatan pelayanan Pemerintahan desa berbasis smart village. Dinamika : Jurnal Ilmiah Ilmu Administrasi Negara, 7(1), 112-120.

Retrieved from https://jurnal.unigal.ac.id/index.php/dinamika/article/view/3420

Polii, R. R., Rindengan, Y. D. Y., \& Karouw, S. D. S. (2017). Analisa Dan Perancangan Sistem Informasi Desa Berbasis Web Model Government-To-Citizen. Jurnal Teknik Informatika, 12(1), 1-7. https://doi.org/10.35793/jti.12.1.2017.17789

Prihatiningtyas, S., Fahimah, M., Ayu, N., Pertiwi, S., Fitri, L., \& Fatikha, L. N. (2020). Optimalisasi Web Desa Mojokambang sebagai Upaya Mempermudah Akses Informasi Penduduk Desa Mojokambang. Jurnal Pengabdian Masyarakat Bidang Informatika, 1(1), 29-34.

https://ejournal.unwaha.ac.id/index.php/abdimas_if/article/download/1051/504

Putri, R. A. (2021). Application of Powtoon Animation as a Learning Media Using the Community Based Participatory Action Research (CBPAR) Method. J-IbM: Jurnal IPTEK Bagi Masyarakat, 1(1), 16-22.

Retrieved from https://journal.aira.or.id/index.php/j-ibm/article/view/2 